\title{
Religious freedom between international law and Tunisia's legal order
}

La libertad de culto entre las leyes internacionales y el ordenamiento legal de Túnez

Autor: Hajer Gueldich

DOI: https://doi.org/10.25058/1794600X.1785

\footnotetext{
Ś MISIÓN JURÍDICA A
} 


\title{
RELIGIOUS FREEDOM BETWEEN INTERNATIONAL LAW AND TUNISIA'S LEGAL ORDER*
}

\author{
La libertad de culto entre las leyes internacionales \\ y el ordenamiento legal de Túnez
}

\author{
Liberdade religiosa entre o direito internacional e a ordem \\ legal da Tunísia
}

\begin{abstract}
Prof. HAJER GUELDICH ${ }^{\mathrm{a}}$
Professor of International Law at the University of Carthage Elected member of the African Union Commission of International Law (AUCIL)
\end{abstract}

hajer.gueldicg@yahoo.fr

Fecha de recepción: 12 de mayo de 2020 Fecha de revisión: 15 de mayo de 2020 Fecha de aceptación: 01 de junio de 2020

DOI: https://doi.org/10.25058/1794600X.1785

Para citar este artículo:

Gueldich, H. (2020). Religious freedom between international law and Tunisia's legal order. Revista Misión Jurídica, 13(20), 40-60.

\begin{abstract}
This paper aims to clarify about Religious freedom in the legal Tunisian framework. It emphasizes Tunisia's choice as a secular state which separates civil state and religion.

Moreover, it highlights the Tunisian exceptionality in its legal achievements in this area, and emphasizes on what differentiates Tunisia from other Arab countries, regarding this protection, especially on - Family status and women rights' related matters. Namely this paper will focus on the last reforms aiming to allow the Tunisian Muslim woman to marry non-Muslim men and to establish inheritance equality between men and women. These new decisions are still controversial for a society divided between progressive Democrats and regressive Islamists.
\end{abstract}

\section{KEY WORDS}

Freedom of religion; freedom of conscience and belief; Islam; secular state; Tunisian Constitution; women rights; family law; inheritance; marriage of Muslim women.

\footnotetext{
a. Mrs Hajer GUELDICH is a Professor of Public Law at the University of Carthage (Tunisia), specialized in International law and responsible of the Master's Degree Program in African Union Law and policy. She is also an elected Member of the African Union Commission on International law (AUCIL) (since 2015) and presently the General Rapporteur of the Commission. She has been an appointed member of the Team of experts of his Excellency Paul Kagame on the Institutional Reform of the African Union, since 2017. Her experience in the field of teaching, since 1999, gives her a large expertise and the opportunity to do several publications in the fields of International law, humanitarian law, human rights, constitutional law, political science, Administrative Organisation, Compared legal systems and transitional periods, in Tunisia and abroad. Her contact with the African Union, as she provides consultation in the field of International law, International criminal law and Integration law, let her to analyze different aspects of African International law, especially within studies aiming to develop International law in the continent.
} 


\section{RESUMEN}

El objetivo de este artículo es aclarar la libertad de culto en el marco legal tunecino. Hace énfasis en la elección de Túnez como estado secular, que separa estado civil y religion.

Por otro lado, destaca la excepcionalidad tunecina en sus avances jurídicos en este área y enfatiza en lo que diferencia a Túnez de otros países árabes, acerca de esta protección, especialmente en cuestiones relativas al estatus familiar o los derechos de las mujeres. Concretamente, este artículo va a enfocarse en las últimas reformas que apuntan a permitir a las mujeres tunecinas musulmanas casarse con hombres no musulmanes y establecer igualdad en la herencia entre hombres y mujeres. Estas nuevas decisiones todavía son controversiales para una Sociedad dividida entre demócratas progresistas e islamistas regresivos.

\section{PALABRAS CLAVE}

Libertad de culto; libertad de conciencia y creencia; Islam; Estado secular; Constitución de Túnez; derechos de las mujeres; derecho de familia; herencia; matrimonio de mujeres musulmanas.

\section{RESUMO}

Este artigo visa esclarecer o respeito à liberdade religiosa no quadro jurídico tunisino. Ele enfatiza a escolha da Tunísia como um estado secular que faz a diferença entre o estado civil e a religião.

Além disso, destaca a exceção da Tunísia em suas conquistas jurídicas nesta área, e enfatiza o que diferencia a Tunísia de outros países árabes, em relação a essa proteção, especialmente nas questões relacionadas ao estatuto de família e direitos da mulher. A saber, este artigo focará nas últimas reformas com o objetivo de permitir que a mulher muçulmana tunisiana se case com o homem não-muçulmano e estabelecer igualdade de herança entre homens e mulheres. Essas novas decisões ainda são controversas por uma sociedade dividida entre democratas progressistas e islâmicos regressivos.

\section{PALAVRAS CHAVE}

Liberdade de religião; Liberdade de consciência e crença; Islamismo; Estado secular; Constituição da Tunísia; Direitos das mulheres; Direito de família; herança; casamento de mulheres muçulmanas.

\section{INTRODUCTION}

The Tunisian population is 98 percent Muslim and overwhelmingly Sunni ${ }^{1}$. Groups that constitute less than 2 percent of the population include Shiaa Muslims, Bahais ${ }^{2}$, Jews, and Christians ${ }^{3}$. Since the Tunisian Revolution for liberty and dignity of 14 January 2011, continuing the democratization process that began in 2011 is fundamental. The 2014 new Tunisian Constitution ${ }^{4}$ upheld many key civil, political, social, economic and cultural rights.

Tunisian State provides for freedom of religion on its Constitutional clause. This rule applies as long as public rights are not harmed in the observation of rituals and practices ${ }^{5}$. However, there are restrictions implemented that favors Islam as a dominant religion $^{6}$. In fact, the presidential seat is exclusive to

1. See BEN ACHOUR, Y. (2008), Aux fondements de l'orthodoxie sunnite, Cérès éditions, Tunis.

2. The Bahá'í Faith is a religion teaching the essential worth of all religions and the unity of all people. Established by Baháu'lláh in 1863, it initially grew in Persia and parts of the Middle East, where it has faced ongoing persecution since its inception. It is estimated to have between 5 and 8 million adherents, known as Bahá'ís, spread throughout most of the world's countries and territories.

See ADAMSON, H. (2006), Historical Dictionary of the Bahá'i Faith, Oxford, UK: Scarecrow Press.

3. https://www.state.gov/documents/organization/171746.pdf

4. The Tunisian Constitution of 2014 was adopted on 26 January 2014 by the Constituent Assembly elected on 23 October 2011 It was passed on 10 February 2014 replacing the constitutional law of 16 December 2011 that temporarily formed the basis of government after the suspension of the Constitution of 1959.

5. See CHARFI, A. (2008), "Islam alibi, islam assumé ", in Mélanges Yadh BEN ACHOUR, Droits et culture, CPU, Tunis, 2008, pp. 71-81.

CHARFI, A. (2004), L'Islam entre le message et l'histoire, Tunis, Sud Éditions.

6. "Tunisia, during the reign of Bourguiba or Ben Ali, is far from being religiously neutral. In the constitution of January 27, 2014 Islam is apprehended both as an identity referent reflecting the socio-cultural and religious traditions of the country but also as the official religion of the State, although the State is proclaimed civil, in accordance with article 2 of the constitution", see LIMAM, .. (2015), "La liberté de religion: les dimension de l'ambivalence", in FERCHICHI, W. (dir.), Libertés religieuses en Tunisie, Conférence de l'ADLI, Tunis, 13 février 2015, FSJPST, p.38. 
Muslims ${ }^{7}$. Furthermore, the Tunisian government assumes authority in the control and regulation of mosques across the country in accordance to the enacted Law on Mosques in $1988^{8}$. Similarly, it pays for the salaries of Muslim prayer and ritual leaders.

As a matter of fact, Islam is the official religion ${ }^{9}$ in Tunisia. But contrary to many Arab states, Tunisia enjoys degrees of secularism and religious tolerance ${ }^{10}$ For instance, there is no penalty for apostasy ${ }^{11}$ in Tunisia ${ }^{12}$.

7. Article 74 of the Tunisian Constitution requires the head of state to be a Muslim. The paragraph 1 of article 74 clearly provides that: "Every male and female voter who holds Tunisian nationality since birth, whose religion is Islam shall have the right to stand for election to the position of President of the Republic". This condition will serve as a permanent bar to any candidates of non-Islamic faith backgrounds or those who are atheists.

8. The Law of 3 May 1988 on Mosques provides that only personnel appointed by the Government may lead activities in mosques and stipulates that mosques must remain closed except during prayer times and other authorized religious ceremonies, such as marriages or funerals. http://www.mdeaf.gov.tn/ images/textes-juridiques/L88-34Fr.pdf

9. "There is no definition which is recognized as valid for religion. The Latin term religio was first defined by Cicero as "taking care of a superior nature that is called divine and to worship him". Religion is often viewed as regarding the relationship between humanity and God", AMOR, A (2010), "Interrogations sur la liberté de religion ou de conviction", in Droit, pouvoir et religion, ATDC, Tunis, page 217 et ss.

10. See MABROUK, M. (2011), "A revolution for dignity and freedom: preliminary observations on the social and cultura background to the Tunisian revolution", in The Journal of North African Studies, 16(4), 625-635.

MEKKI, N. (2020), " The democratic transition in Tunisia: Three explicative keys to understand a success story ", in EL ISSAWI $F$ and CAVATORTA F. (ed), The Unfinished "Arab Spring", Micro Dynamics of Revolts Between Change and Continuity, University of Chicago Press/Ginko Press.

PERKINS, K. (2014), A History of Modern Tunisia (2nd ed.), Cambridge: Cambridge University Press.

11. Apostasy means "the formal disaffiliation from, or abandonment or renunciation of a religion by a person. It can also be defined within the broader context of embracing an opinion contrary to one's previous beliefs", see BROMLEY, D-G. (1988), Falling From the Faith: The Causes and Consequences of Religious Apostasy. Beverly Hills: Sage.

Apostasy also means " voluntary and public abandonment of a religion, in particular, the Muslim religion. Thus, the apostate opposes the believer. In Muslim law, the apostate is any person who denies "a religious thing necessarily known". Apostasy, however, has an ambiguous, vague and ambivalent character, the meaning of which differs from one doctrine to another", see BEN ACHOUR, R. and GUELDICH, H. (dir) (2017), Dictionnaire de la nouvelle Constitution Tunisienne, Tunis, Simpact, p.35, https:// drive.google.com/drive/u/1/folders/1GCA8DHHKPKYVrRwsk GjK392_me9Ccvz

12. Article 6 paragraph 2 of the Tunisian Constitution of 2014 provides that: " The state undertakes to disseminate the values of moderation and tolerance and the protection of the sacred, and the prohibition of all violations thereof. It undertakes equally
The freedom of religion is defined as "the freedom for any individual to adhere to the confession of his or her choice; or to reject them all (freedom of conscience), to express and teach their beliefs and beliefs (freedom of opinion) and public worship corresponding to his faith (freedom of worship)"13. The freedom of religion regroups at the same time the freedom of conscience, the freedom of opinion and the freedom of worship ${ }^{14}$

There is no doubt that "corresponding to the 20th century trend toward democratization is the evolution of religious liberty as a fundamental human right. Democracies are structured to accommodate difference and most countries today are populated by people with a range of religious commitments; thus religious liberty now is considered a basic human right"15.

In Tunisia, the freedom of religion is not only a legal framework, it is also a style of life that was introduced by the first Tunisian President Habib Bourguiba $^{16}$. According to M. Camau, «Tunisia is one of the most modernist states of the Arab-Muslim world"17. Furthermore, Tunisian lawmakers have successfully established "the synthesis between the Muslim heritage and the imperatives of modernity"18. This was clearly mentioned in the paragraph 4 of the Preamble of the 2014 Tunisian Constitution ${ }^{19}$.

to prohibit and fight against calls for Takfir (apostasy) and the incitement of violence and hatred".

13. CORNU, G. (2000), Vocabulaire juridique, Association Henri Capitant, PUF.

14. BEN ACHOUR, R. and GUELDICH, H. (dir) (2017), Dictionnaire de la nouvelle Constitution Tunisienne, op.cit., p. 230.

15. DAVIS, D. (2006), "The Evolution of Religious Liberty as a Universal Human Right", in Democracy dialogues freedom of religion,

https://web.archive.org/web/20080201105738/http://usinfo. state.gov/dd/eng_democracy_dialogues/religion/religion_essay. html

16. Habib BOURGUIBA (3 August 1903 - 6 April 2000) was a Tunisian lawyer, nationalist leader and statesman who served as the country's leader from independence in 1956 to 1987.

See BELKHODJA, T. (1998), Les trois décennies Bourguiba. Témoignage, Paris, Publisud.

CAÏD ESSEBSI B.. (2009), Bourguiba. Le bon grain et l'ivraie ,Tunis: Sud Éditions.

17. CAMAU, M. (1981), "Religion politique et religion d'Etat en Tunisie". In Islam et politique au Maghreb, Table ronde du CRESM, Aix, juin 1979, Editions du centre national de la recherche scientifique, Paris, page 221.

18. AMOR, A. (2010), "Interrogations sur la liberté de religion ou de conviction ", in Droit, pouvoir et religion, A.T.D.C., p. 217.

19. According to paragraph 3 of the 2014 Tunisian Constitution, "Expressing our people's commitment to the teachings of Islam 
As the Tunisian family status Laws both recall their attachment to Islam and call for moderation, Tunisia continues to distinguish itself from all Arab and Muslim countries. In fact, by removing the Personal Status from the grip of Islamic law and entrusting it to the State in 1956, President Habib Bourguiba accomplished an important qualitative leap in the secularization of Tunisian law. But he had not wished to make a clean break with the reference to religion.

Moreover, Tunisia is seen as a pioneer in the Arab world since the adoption of the Code of Personal Status in $1956^{20}$, most notably including the abolition of polygamy, forced marriages and repudiation. But the former President Habib Bourguiba did not manage to give Tunisian women equality in inheritance then. The case has thus been brought back to the table (60 years later) in a divided society.

Contrary to Algerian, Moroccan and Egyptian laws, Tunisian legislation makes no reference to Sharia ${ }^{21}$ to fill gaps in the Personal Status Code or to interpretation of the Code in the event of ambiguity. "Indeed, judges rely on the reference to Islam in Article 1 of the Constitution to apply the rules of Muslim law in the event of ambiguity or silence of the law $^{22}$. This traditionalist current is being called into

and its aims characterized by openness and moderation, and to the human values and the highest principles of universal human rights, and inspired by the heritage of our civilization, accumulated over the travails of our history, from our enlightened reformist movements that are based on the foundations of our Islamic-Arab identity and on the gains of human civilization, and adhering to the national gains achieved by our people".

20. The Tunisian Personal Status Code was promulgated by Beylical decree on August 13, 1956 and came into effect on January 1, 1957. It is regarded as the legislative text which departs the furthest from the Islamic norms that previously governed personal status in Tunisia and the most favorable to women's rights in any Arab-Muslim country. A set of laws regulating marriage, divorce, custody, and inheritance, the Code profoundly changed family law and the legal status of women. "Together with the Turkish civil Code of 1926, the Tunisian CPS of 1956 represented a pioneering body of legislation that reduced gender inequality before the law in an Islamic country", see https://www.encyclopedia.com/humanities/encyclopediasalmanacs-transcripts-and-maps/tunisia-personal-status-code .

21. Sharia (also known as "Shariah" or "Shari'a") is an Islamic religious law that governs not only religious rituals but also aspects of day-to-day life in Islam. Sharia, literally translated, means "the way."

There is extreme variation in how Sharia is interpreted and implemented among and within Muslim societies today, see https://www.investopedia.com/terms/s/shariah.asp

22. BEN LAMINE, M. (2010), "L'interprétation de l'article 1er de la Constitution tunisienne au regard de la liberté de conscience: quel risque?", p.5.

https://cerclechercheursmoyenorient.wordpress. question and a modern conception of the Tunisian family Law is more and more effective in Tunisia especially during the last few years.

Besides, it is important to observe that Tunisia has numerous factors that facilitate a democratic transition process, such as high education rates, liberal elites, a consensus-oriented tradition, an important broad and educated middle class, an active civil society and a moderate practice of Islam, etc. The constellation of all these factors renders the Tunisian democratic consolidation case specific and successfully contributed to achieving the Constitution consensus in 2014. This process was peaceful and unique, in comparison with other Arabic countries of the "Arab spring"23.

Tunisian society is characterized by toleration of the religious citizens towards the state, and the toleration of state officials and state law to permit religious citizens to freely express their views and values within civil society and in politics, as long as other citizens' constitutional rights and the law are respected.

However, the Tunisian society has to face the tensions between the secular and the Islamist bloc,

com $/ 2010 / 10 / 19 /$ linterpretation-de-larticle-1er-delaconstitution-tunisienne-au-regard-de-la-liberte-deconscience-quel-risque/

23. The newly emerging Tunisian political system needs to be considered in the context of the current developments in the wider MENA region. In the international political debate on the "Arab Spring", the Tunisian case has often been cited as a "model" of peaceful and successful transition. The Tunisian transition is considered as a very particular and unique case, and not as a "model".

Moreover, "compared to other (failing or not failing) states in the MENA region, it is indeed the only country where a comprehensive process of democratic consolidation is taking place so far. The hitherto success of the Tunisian transition results from the particular constellation of the Tunisian case, including the constructive combination of different factors such as a strong civil society, strong middle class, low level of armament, consensus-oriented tradition, high level of education, or the absence of violent ethnic conflicts. All these factors suggest that the perspectives for a long-term democratic transformation process look positive but the challenges remain multifaceted", SCHÄFER, I. (2015), The Tunisian Transition: Torn Between Democratic Consolidation and Neo-Conservatism in an Insecure Regional Context, European Institute of the Mediterranean. https://www.die-gdi.de/uploads/media/Tunisian_Transition_ EuroMeSCo_Paper_25_Isabel_Schaefer.pdf

See also ANDERSON, L. (2011), "Demystifying the Arab Spring: Parsing the Differences between Tunisia, Egypt, and Libya", in Foreign Affairs, 90(2), 2-7.

JOFFE, G. (2011), "The Arab Spring in North Africa: origins and prospects", in North African Studies, 16(4), 507-532. 
since $2011^{24}$. And in spite of the numerous polemics created by the Islamist party Ennahdha ${ }^{25}$, especially its intention to introduce the Sharia as a source of law in 2012, all these polemics and controversies are outdated today.

The Tunisian society succeeded to overpass all the challenges related to the acceptance of the other's opinions in a country that discovers again and again its identity. As a matter of fact, "Toleration and the accommodation of differences initially enabled Tunisia to integrate important political actors into the transitional process, to hold elections and, thus far, to navigate the divisions between secular and religious Tunisians"26.

At the international level, religious freedom is recognized by International texts and instruments on human rights. It goes hand in hand with freedom of thought and freedom of conscience. Tunisia, in comparison with the other Arabic and Muslim countries, is a pioneer in the field of respecting religious liberties, especially when it is question of women rights and family law.

This panorama leads as to ask one fundamental question: what should be the role of religion in the Tunisian positive law in a country that advocates the civil character of the state ? In other words, it is legitimate to wonder about the real place of Islam within the Tunisian Constitution of 2014 and other relevant legal instruments?

How can Tunisia, a secular nation according to its constitution in consonance with certain elements of international law, guarantee fundamental rights of its citizens irrespective of their faith?

24. See IHSAN, M. and ZEBA, Kk. (2011), "Secular-religious tensions in Tunisia since 2011", in KUMARASWAMY, Pr. and al, Islamic movements in the Middle east: ideologies, practices and political participation, KW Publishers, New Delhi, pp. 143-167.

AL-ANANI, K. (2012), "Islamist Parties Post-Arab Spring", in Mediterranean Politics, 17(3).

SCHÄFER, I. (2015), The Tunisian Transition: Torn Between Democratic Consolidation and Neo-Conservatism in an insecure region context, IeMed and EuroMesco, 2015.

25. After the events of January 14, 2011, Tunisia experienced a profound metamorphosis of the political landscape, notably with the reappearance of the Islamist movement embodied by the Ennahdha party which managed to let its religious imprint in the Tunisian Constitution of January 2014 in through the diversification of religious referents.

26. SHELLEY, De. (2013), Transforming Tunisia The Role of Civil Society in Tunisia's Transition, International Alert, page 6.
As a matter of fact, the Tunisian Constitution of 2014 recognized clearly the religious freedom and freedom of conscience. Moreover, some other issues demonstrate the willing of the Tunisian government to separate the religion and the rule of law.

However, certain practices and cases of jurisprudence show that the religious' share in the experience of the Tunisian people is still omnipresent. They also show that despite a wide margin of freedom and secularism, the majority of the Tunisian people are still conservative and very attached to religious traditions and precepts.

This will lead us to explore the Tunisian national legal framework in the field of religious freedom, freedom of conscience and belief and to highlight what were the innovations of the new Tunisian Constitution of 2014 in this field (I).

This is to show how original the Tunisian family status Law and the Tunisian women's rights are, especially since the reforms of 2017 (II).

Moreover, the recent proposals to reform both the marriage of a Muslim women to a non Muslim (III) and the inheritance law in Tunisia (IV), in spite of the controversies they still arise, are the proof of a dynamic society that is still trying to respect Democracy, Human rights and State of law.

Although international standards on the matter are theoretically respected in Tunisia, it is obvious that the challenges for consolidating a democratic system are still numerous and multifaceted (V). We will finish our paper by concluding that religious freedom in Tunisia, in spite of the huge efforts done in this context, still needs to be reinforced and guaranteed.

\section{SECTION 1.NATIONAL LEGAL FRAMEWORK FOR RESPECT OF RELIGIOUS FREEDOM AND INNOVATIONS OF THE TUNISIAN CONSTITUTION}

The new Tunisian Constitution was written in $2014^{27}$. The first article of the Constitution makes it clear where it stands on religion and the state ${ }^{28}$.

27. The Tunisian Constitution of 2014 was adopted on 26 January 2014 by the Constituent Assembly elected on 23 October 2011. It was passed on 10 February 2014.

28. Secular political parties operating within the Constituent Assembly in Tunisia in 2011, including the Congress Party for the Republic and Ettakatol, opposed Ennahdha's attempts to incorporate additional references to Islamic law in the 
As a matter of fact, this article 1 stipulates that: " Tunisia is a free, independent, sovereign state; its religion is Islam, its language Arabic, and its system is republican. This article might not be amended".

But article 1 should be read in parallel with article 2 of the Constitution which underlines the civic nature of the State as laid down in this Article 2 that states: "Tunisia is a civil state based on citizenship, the will of the people, and the supremacy of law. This article might not be amended". This article of the Constitution clearly underlines the civil nature of the Tunisian state and the sovereignty of the people ${ }^{29}$. That shows how important the question of separation between religion and state is, in a modern country which had made the choice to be a secular country, since its independence in 1956 and since its first Constitution of $1959^{30}$

Constitution. Representatives of these parties announced that Ennahdha's proposed constitutional provision emphasizing Islam as the main source of legislation was unacceptable because Ennahdha did not identify which interpretation of Islamic law Tunisians should follow.

During 2012, it was reported that the Ennahdha party agreed that there is no need to insert a special provision declaring Islam the main source of legislation because article 1 of the old Constitution of 1959 already mentions that "Islam is the religion of Tunisia." After months of debate and negotiations, on March 26, 2012, Ennahdha announced that it would no longer press for the inclusion of this provision.

Most of the secular and religious political parties in Tunisia agreed to keep article 1 of the old Constitution, which explicitly states that "Tunisia is a free, sovereign and independent state, whose religion is Islam."

See PICKARD, D. (2012), "The Current Status of Constitution Making in Tunisia, Carnegie Endowment For International Peace" (Apr. 19, 2012), http://carnegieendowment.org/2012/04/19/ current-status-of-constitution-making-in-tunisia/ah1s.

GOODENOUGH, P. (2012), "Sharia Rises in Tunisia's ConstitutionDrafting Process", cnsnews.com (Mar. 2, 2012)

MANAA, M. (2012), "Tunisia's Constitution: The Battle for Islam and Democracy", Fair Observer (Dec. 7, 2012), http://www. fairobserver.com/article/tunisias-constitution-battle-islamdemocracy.

LAMBOLEY C. (2012), "Tunisia's Leading Party Reaffirms Commitment to Arab-Muslim Identity", Tunisialive (Mar. 25, 2012), http://www.tunisia-live.net/2012/03/26/tunisiasleading-party-reaffirms-commitment-to-arab-muslim-identity/

29. See BEN ACHOUR, Y. (2014), "Le compromis historique entre "Etat civil » et religion dans le néo-constitutionnalisme arabe post-révolutionnaire", http://yadhba.blogspot.com/2014/09/

30. According to Article 5 of the 1959 Tunisian Constitution: " 1. The Republic of Tunisia shall guarantee fundamental freedoms and human rights in their universality, comprehensiveness, complementarity and interdependence. 2. The Republic of Tunisia shall be founded upon the principles of the rule of law and pluralism and shall strive to promote human dignity and to develop the human personality. 3. The state and society shall strive to entrench the values of solidarity, mutual assistance and tolerance among individuals, social categories and generations. 4. The Republic of Tunisia shall guarantee the inviolability of the human person and freedom of conscience, and defends the free practice of religious beliefs provided this does not disturb public order".
In the new Tunisian Constitution of 2014, the article 6 is more explicit. It is almost the same as article 5 of the 1959 Constitution ${ }^{31}$, but it adds the recognition of the freedom of conscience. Article 6 of the Constitution of 2014 is dedicated to " Freedom of opinion/thought/conscience". It stipulates that: "1. The state is the guardian of religion. It guarantees freedom of conscience and belief, the free exercise of religious practices and the neutrality of mosques and places of worship from all partisan instrumentalization. 2. The state undertakes to disseminate the values of moderation and tolerance and the protection of the sacred, and the prohibition of all violations thereof. It undertakes equally to prohibit and fight against calls for Takfir (apostasy) and the incitement of violence and hatred".

This article can be regarded as a constitutional revolution in Tunisia ${ }^{32}$, as it is the first provision in an Arab and Islamic State which explicitly enshrine "freedom of conscience" 33 .

The freedom of conscience means that a person believes in what dictated by his personal conviction that require a choice between different opinions in philosophical thinking and ethical and political options. The freedom of conscience is the freedom of the individual to choose the values that define its relationship with the wilderness, with relative autonomy among of the community ${ }^{34}$.

\section{Idem. op; cit}

32. According to Khaled DABBABI, "this article can be considered as a constitutional and civilization revolution as it is the first constitutional provision of an Arab and Islamic country to have clearly and expressly introduced freedom of conscience", in $D A B B A B I, K h$. (2015), "La liberté religieuse dans la Constitution tunisienne du 27 janvier 2014", in BEN ACHOUR, R. (dir.) (2015), Les nouvelles Constitutions arabes: Tunisie, Egypte (ouvrage collectif), Actes du colloque organisé par l'Unité de recherche en droit international, juridictions internationales et droit constitutionnel comparé, Tunis , 29 février et 1 mars 2014, Tunis, Simpact, p. 72 .

33. See BEN ACHOUR, Y. (2014), "The freedom of conscience", http://yadhba.blogspot.com/2014/01/

34. Concerns regarding Takfir or apostasy in Tunisia grew during constitutional debates when a member of the Tunisian Parliament was called an "enemy of Islam" by a member of the Ennahda Party, which is an Islamist party. It is important to recall that "Ennahda had originally wanted Article 6 to enshrine Islam as the state religion, but this

controversy led to opponents pushing harder for freedom of conscience and religion to be

included in the Article. Due to concerns over religious extremism and violence, secular political

parties were able to add a prohibition of both Takfir and "incitement of violence" to Article 6. Altogether, Article 6 of the 2014 Constitution serves to promote freedom of religion and prevent

religious violence in a manner that is very strong relative to the protections afforded to religious 
That freedom of conscience is located in the middle of the road between freedom of thought and freedom of religion. In this sense, beyond the narrow concept of freedom of conscience, freedom of belief, it does not mean only the right to choose between one of religions, but also and, in particular, the right to believe or not believe. It also enables the freedom of conscience of the change of religion ${ }^{35}$.

Besides, the article 31 of the 2014 Constitution reinforce this idea by stipulating the following: " Freedom of opinion, thought, expression, information and publication shall be guaranteed. These freedoms shall not be subject to prior censorship".

This is exactly what said the several provisions that are made at the International level and that Tunisia had signed and ratified ${ }^{36}$.

Meanwhile, it's important to observe that freedom of opinion, thought, expression, information and publication in Tunisia are not without any limitation. Therefore, these freedoms may be limited as this limitation is necessary for the protection of security or public order, as well as public health or morality.

Theses liberties, including the religious freedom, are limited by national defense, public health or public morals, as provided by article 49 of the Tunisian Constitution according to which: " 1 . The limitations that can be imposed on the exercise of the rights and freedoms guaranteed in this Constitution will be established by law, without compromising their essence. Any such limitations can only be put in place for reasons necessary to a civil and democratic state and with the aim of protecting the rights of others, or based on the requirements of public order, national defense, public health or public morals, and provided there is proportionality between these restrictions and the objective sought. 2.Judicial authorities ensure that rights and freedoms are protected from all violations. 3. No amendment may undermine

freedom in other Arab countries", BITZ, A. (2019), "Freedom of Religion in the 2014 Tunisian Constitution", International Immersion Program Papers, 100.

https://chicagounbound.uchicago.edu/international_ immersion_program_papers 100

35. Such is the recognition of the freedom of conscience which is a unique precedent in the Arab Islamic constitution, as it is a recognition of the triumph of freedom, based on the absolute freedom of thought and belief and adopting with the Qur'anic approach based on the principle of "no compulsion in religion" (meaning, "Do not force anyone to become Muslim"), [Surat alBaqarah, 256].

36. See section 5 of this paper. the human rights and freedoms guaranteed in this Constitution".

The constitutionalisation of freedom of conscience in Tunisia is an important result as "it constitutes a strong card not only for fighting violations of this fundamental right but also for abrogating the laws and regulations that obstruct it, reporting and prosecuting those who infringe it and establishing full citizenship, without anyone suffering discrimination in the name of religion"37.

As a matter of fact, the "religious question" remains lively in the Tunisian Constitution of $2014^{38}$ and is "endowed with a particular weapon which prevents its total submission to the state. This weapon

37. FERJANI, M-C. (2018), "Tunisia: between Freedom of Conscience and Protection of the Sacred", Religion and society, April 2018, https://www.oasiscenter.eu/en/tunisia-freedom-ofconscience-protection-of-sacred

38. See BEN ACHOUR, Y. (2016), Tunisie: une révolution en pays d'islam, Cérès éditions, Tunis.

BEN ACHOUR, Y. (2011), La deuxième Fâtiha: l'islam et la pensée des droits de l'Homme, Cérès éditions, Tunis.

BEN ACHOUR, Y. (2008), Aux fondements de l'orthodoxie sunnite, Cérès éditions, Tunis.

BEN ACHOUR, Y. (2008), "Droits du croyant et droits de l'homme, Un point de vue islamique", islamo-christiana, Roma, $N^{\circ} 39$.

BEN ACHOUR, Y. (1993), Normes, foi et loi, Cérès éditions, Tunis.

DJAIT, $H$. (2013), La crise de la culture islamique, Cérès éditions, Tunis.

HAMMAMI, N. (2018), "La société tunisienne à l'égard de la liberté religieuse et de la conviction selon "le rapport sur l'état religieux en Tunisie (2011-2015) ", in Liberté de religion et de conviction en Méditerranée :les nouveaux défis, Beit Al-Hikma - Carthage, conférence internationale des 27 et 29 septembre 2018.

HAMDAM, N. (2013), La liberté de religion dans les Etats de droit musulman. Droit. Université Jean Monnet - Saint-Etienne.

KLIBI, S. (2008), "Etat de droit, Etat laïque : Liberté religieuse ou déni de la religion? ?, in Mélanges Yadh BEN ACHOUR, Droits et culture, CPU, Tunis, pp. 153-169.

LAGHMANI, S. (2000), "Entre Etat laïc et Etat confessionnel : Un statut intermédiaire est-il pensable?", in Mélanges en l'honneur de Habib Ayadi. Tunis, CPU, pp.625-633.

LHERNOULD, N. (2014), "Nouvelle constitution tunisienne et liberté de conscience", in L'ouvre d'orient, https://oeuvreorient.fr/actualites/nouvelle-constitution-tunisienne-liberte-deconscience/

LIMAM, J., (2015), "La liberté de religion: les dimensions de l'ambivalence", in FERCHICHI, W. (dir.), Libertés religieuses en Tunisie, Conférence de l'ADLI, Tunis, 13 février 2015, FSJPST, pp. 34-58.

REDISSI, H. (2011), La tragédie de l'Islam moderne, Cérès éditions, Tunis

REDISSI, H. (2005), L'exception islamique, Cérès éditions, Tunis. SAYADI, A. (2018), "Peut-on séparer le religieux et le politique dans un pays musulman? Que nous dit l'expérience tunisienne ?", in Liberté de religion et de conviction en Méditerranée :les nouveaux défis, Beit Al-Hikma - Carthage, conférence internationale des 27 et 29 septembre 2018.

TALBI, M. (2011), Ma religion c'est la liberté: I'Islam et les défis de la contemporanéité, Nirvana éditions, Tunis.

TALBI, M. (1998), Plaidoyer pour un Islam moderne, Cérès éditions, Tunis. 
is the vagueness of the 2014 Constitution which brings together, in a schizophrenic text, opposing principles and concepts that make the task of any interpreter of the constitution difficult. This difficulty in interpretation makes it possible to prolong, over time, the state of vagueness in the supreme text and allows religion, in spite of its weakness, to slip insidiously and, more and more, into the cogs of the 'State"39.

However, when it is question of practice, it is not always easy for the Tunisian authorities to respect these principles ${ }^{40}$. Even if the new constitution of 2014 is often represented as a bulwark against any attempt to infringe fundamental freedoms, whose freedom of religion, it seems, obviously, that the reconciliation between the protection of Islam, religion of almost all Tunisian citizens, and the guarantee of the right to freedom of conscience and the exercise of other cults, is not easy.

Meanwhile, the respect of these imperatives is not without raising difficulties and sometimes even antagonisms. In fact, some examples can be mentioned to show violations of the freedom of conscience by public authorities in Tunisia ${ }^{41}$.

39. GOUIA, S. (2015), "La religion dans la nouvelle constitution tunisienne du 27 Janvier 2014 : Contexte et problématique", in Mélanges Rafaâ BEN ACHOUR, Les mouvances du droit, tome 1, p. 375 .

40. Individual liberties in 2019: The danger of populism, The civil collective for individual liberties, Tunis, Report of April 2020, http://www.adlitn.org/en/node/5311

41. 1. On 2 May 2019, Academic researcher Saloua Charf appeared before the crime squad on the basis of a post published on her facebook official page where she was criticizing the Jihad in Islam, see: http://www.adlitn.org/sites/default/fles/revue de presse mensuelle adli_avril_2019.pdf

2. A café owner in Kairouan (Tunisia) was convicted of publicly offending morality on May 29, 2019 for keeping his café open during Ramadan fasting hours, Human Rights Watch has reported. Such prosecutions, using a vague provision that is applied sporadically and inconsistently, constitute an arbitrary use of the criminal law. He spent 10 days in jail before a court sentenced him to a suspended term of one month in prison and a fine of 300 dinars, see: https://www.hrw.org/news/2019/06/07/ tunisia-cafe-owner-jailed-over-ramadan-hours

3. The Public Prosecutor's Office of the First Instance Tribunal of Ben Arous ordered the appearance of 4 students (girls) aged 16 years old before the crime prevention brigade for having published videos "undermining Islam and the prophet Mohamed". According to Shems Fm, the 4 girls were released after having been heard by the Judicial Police Brigade, see: https://www. realites.com.tn/2019/11/4-lyceennes-devant-la-justice-pouratteinte-a-lislam/

4. Public displays of affection, such as kissing in public, have been interpreted as acts of public indecency, and this law was used by authorities in prosecuting individuals. This was the case when a couple was arrested in October 2017 for kissing in a car. The man, who holds French and Algerian citizenship, was sentenced to a prison term of four and a half months, though he was liberated after spending two and a half months behind bars.

\section{SECTION 2. INNOVATIONS IN TUNISIAN FAMILY LAW AND WOMEN RIGHTS IN RESPECT WITH RELIGIOUS FREEDOM}

Tunisia is the fastest country to progress in the area of women's rights and sets an example for many other Arab countries from Middle East. Moreover, the Family law in Tunisia has detached itself from the precepts of Islam. To this end, it has abolished the repudiation, admitted the monogamous marriage, recognized the adoption, consecrated the custody is granted to one of the parents based on the best interests of the child.

However, the provision of article 1 of the Tunisian Constitution has often been invoked by the supporters of tradition to justify the application of the rule of law by judges in the event of ambiguity or silence in the personal status Code.

This can be easily surpassed if we make interpretation of the article 1 on the light of article 2 of the Constitution which provides that: "Tunisia is a civil state based on citizenship, the will of the people, and the supremacy of law".

A "civil state" 42 means "a secular state" 43 . A secular state is an idea pertaining to secularity, whereby a state is or purports to be officially neutral in matters of religion, supporting neither religion nor irreligion ${ }^{44}$. A secular state also claims to treat all its citizens equally regardless of religion, and claims to avoid preferential treatment for a citizen from a particular religion over other religions.

His Tunisian companion was sentenced to a three-month prison terms. The "kiss affair" raised a lot of controversy in Tunisia and a debate about an ultra-conservative police and judiciary. In addition to public morality charges, the couple was accused of "offending a public official" when they allegedly challenged the police officers' statements, see Personal Freedoms and Public Morality in Tunisia, TIMEP Brief,13 June 2018, https://timep. org/reports-briefings/timep-brief-personal-freedoms-andpublic-morality-in-tunisia/.

42. May be the English official translation of the Constitution is not referring to the right expression. Civil state means secular state.

43. To be more precise, "a civil state" is not always synonymous with "secular state" which, according to the definition most frequently used, indicates the State which does not intervene in relation to religious questions or who adopts an attitude of neutrality and impartiality towards religions. See BEN ACHOUR, $R$. and GUELDICH, H. (dir) (2017), Dictionnaire de la nouvelle Constitution Tunisienne, op.cit., p. 167.

44. See TEMPERMAN, J. (2010), State Religion Relationships and Human Rights Law: Towards a Right to Religiously Neutral Governance, BRILL. 
Secular states do not have a state religion or an equivalent, although the absence of an established state religion does not necessarily mean that a state is fully secular in all respects ${ }^{45}$.

Tunisia is a country in which most people are Muslim, however this does not mean that Islam is a source of law. It can be of great inspiration in some issues, but the choice of the state was not to have Sharia as a source of its law ${ }^{46}$.

Moreover, Tunisia has a unique set of family law codes that continue to operate from 1956 to the present day. The 1956 Code of Personal Status deals with crucial issues such as marriage, divorce, inheritance, alimony, child custody and adoption ${ }^{47}$. Since 1956, for example, Tunisia admitted the monogamous marriage ${ }^{48}$, recognized the adoption and abolished repudiation ${ }^{49}$.

Recently, Tunisia abolished the law according to which that if a rapist married their victim then they would be set free of all abusive charges ${ }^{50}$. Even if these

45. For example, many secular states have religious references in their national anthems and flags.

46. The Tunisian constituent erected the civil character of the State as an intangible principle in the sense that it cannot be subject to a constitutional revision (according to paragraph 2 article 2 of the Tunisian Constitution).

See BAKIR, M. (2016), Laïcité et religion en Tunisie, Thèse de doctorat, Linguistique, Soutenue le 16 septembre 2016, Université de Strasbourg.

47. See KHEDHER, R. (2017), "Tracing the Development of the Tunisian 1956 Code of Personal Status", in Journal of International Women's Studies, 18(4), 30-37. Available at: http://vc.bridgew.edu/jiws/vol18/iss4/3

BEN HALIMA, S. (2000), « Religion et Statut Personnel en Tunisie ", in Revue Tunisienne de Droit, pp. 107 et ss.

BEN JEMIA, M. (2007), "Constitutionnalisation du droit et mutation du statut personnel", in Cours de l'académie internationale de droit constitutionnel, 23ème session, Tunis 2007, pp. 1 et ss.

BOUGUERRA, M. (2005), "Le Code tunisien du statut personnel, un code laïque? » in Mélanges Sassi BEN HALIMA, Mouvements du droit contemporain, CPU, Tunis, pp. 529-581.

MEZIOU, K. (2017), " Le Code du statut personnel : le texte et le contexte", in $M^{\prime} R A D, H$. (sous dir.), Transitions arabes: Révoltes, Gouvernance et Géopolitiques, Tunis, éditions Nirvana, pp. 161172.

48. See LARGUECHE, D. (2010), "Monogamy in Islam: The case of a Tunisian Marriage Contract", Occasional Paper of the IAS School of Social Science (2010), http://www.medievalists. net/2011/01/monogamy-in-islam-the-case-of-a-tunisianmarriage-contract/

49. KHEDHER, R. (2017), "Tracing the Development of the Tunisian 1956 Code of Personal Status", in Journal of International Women's Studies, 18(4), 30-37. Available at: http://vc.bridgew.edu/jiws/vol18/iss4/3

50. https://www.amnesty.org/en/latest/campaigns/2015/12/ laws have been overturned, Tunisian women, along with many Muslim women around the world, still face gender discrimination and abuse.

It is important to notice that in Article 21, the Tunisian Constitution stipulates that: "All citizens, male and female, have equal rights and duties, and are equal before the law without any discrimination". Article 46 states: "The state commits to protect women's accrued rights and works to strengthen and develop those rights. The state guarantees the equality of opportunities between women and men to have access to all levels of responsibility in all domains".

Tunisia is also bound by the UN Convention on the Elimination of All Forms of Discrimination Against Women (CEDAW) ${ }^{51}$, ratified in 2014 by the Tunisian Parliament ${ }^{52}$. In contrast, the Tunisian Personal Status Code, which regulates family issues, stipulates that the Sunni Islamic jurisprudence should be applied to inheritance issues. This will be amended soon ${ }^{53}$.

However, it remains undeniable that the civil character of the State enshrined in Article 2 of the Tunisian Constitution helps to put into perspective the ambiguity around the holder of Islam and has the effect of ruling out any possibility of transforming the Tunisian state into theocratic or religious state.

As a matter of fact, by multiplying the references to the "civil character of the State", the Tunisian Constitution of January 2014 seems to accord this element a privileged status in the constitutional order. Already in the fourth paragraph of the preamble of the 2014 Constitution, the civil character is asserted. It is even considered to be the ideal setting for fulfillment of a republican, democratic and participative regime.

my-body-my-rights-tunisia/

51. The United Nations on April 23, 2014, confirmed receipt of Tunisia's notification to officially withdraw all of its specific reservations to the treaty known as the Convention on the Elimination of All Forms of Discrimination against Women (CEDAW). These reservations had enabled Tunisia to opt out of certain provisions, including on women's rights within the family, even though the country had ratified the treaty. Tunisia started this process in 2011, but only in recent days formally notified the UN. Tunisia is the first country in the region to remove all specific reservations to the treaty, https://www.hrw.org/ news/2014/04/30/tunisia-landmark-action-womens-rights

52. Furthermore, reservations to the Convention on the Elimination of All forms of discrimination against women (CEDAW), in particular the general reservation that the Tunisian State will not take any action contrary to article 1 of the constitution, were lifted under the Law Decree of October 24, 2011.

53. See section 4 of this paper. 
In this regard, the paragraph 4 of the Preamble of the Constitution provides that: "With a view to building a republican, democratic and participatory system, in the framework of a civil state founded on the sovereignty of the people, exercised through the peaceful alternation of power through free elections, and on the principle of the separation and balance of powers (...)".

Besides, and as demonstrated above, article 1 of the Tunisian Constitution can only be read and interpreted on the light of article 2, according to which the Tunisian civil state is based on citizenship, the will of the people and the rule of law.

\section{SECTION 3. EVOLUTION OF THE QUESTION RELATED TO THE MARRIAGE OF A MUSLIM WOMAN TO A NON-MUSLIM MEN}

According to a broad consensus religiously sterile, a Muslim woman is formally forbidden to marry a non-Muslim man regardless of his religion, while a Muslim man is allowed to get married to a non Muslim woman, mainly a Christian or a Jew, considered by the Islamic schools as "People of the Book"54. But forbidding the marriage of a Muslim woman to a Christian or a Jewish man is not based on any Quranic text or saying of the Prophet, but rather on a mutual agreement of scholars of all eras ${ }^{55}$.

As a matter of fact, before 2017, a non-Muslim man who wished to marry a Tunisian Muslim woman had to convert to Islam and submit a certificate of his conversion as proof ${ }^{56}$.

Nothing expressly prohibits the marriage of the Muslim woman to a non-Muslim in Tunisian law (contrary to the laws of others

54. Mohamed Tahar Ben Achour assumed the inexistence of a religious text that allows or forbids the marriage of Muslim women to Christian or Jewish men. He added that scholars agreed to forbid such marriage for several reasons related to the analogy (al quiyāss) and consensus (Ijmā'), while they confess that there exist no specific reasons of this prohibition in the religious text, BEN ACHOUR, M-T. (2008), Tafssir Atahrïr wa tanwìr of Ibn Achour, p. 359, Vol 1-2.

55. The very rare hadiths that forbid the marriage of Muslim women to "People of the Book" are considered as weak according to the opinion of the majority of scholars. See ATTABARI, http:// www.asma-lamrabet.com/articles/what-does-the-qur-an-sayabout-the-interfaith-marriage/

56. See NOUIRA, A. (2008), «Le mariage de la tunisienne musulmane avec un non musulman : Dépassement ou transgression des frontières? ", GRIC. countries such as, for example, Morocco, Algeria and Jordan). The Tunisian jurisprudence and Tunisian administrative practice was based on a restrictive interpretation to be given to article 5 of the Personal status Code in its Arab version to prohibit the marriage of a Muslim woman to a non-Muslim $\operatorname{man}^{57}$.

Since September 2017, Tunisian women are free to marry non-Muslims. President Beji Caid Essebsi $^{58}$ repealed the decree $n^{\circ} 606$ dated 19 October 1973, inspired by the country's Muslim traditions that previously required non-Muslim men to convert to Islam in order to marry a Muslim woman ${ }^{59}$.

The new law comes after the former Tunisian President Beji Caid Essebsi pushed for the lifting of the marriage restriction decree that was put in place in $1973^{60}$. In his speech, he said: "It is necessary to develop personal status laws in such a way to promote equality and to keep pace with modern legislation and changing modern times. This is especially true since law No. 73 (which bans Tunisian women from marrying non-Muslim men ) has become an obstacle to the freedom of choice of the spouse. This is also necessary for the legal status of many [Tunisian] women married to foreigners. One ought to bring to mind as well Article 6 of the Tunisian constitution, which recognizes the freedom of belief and conscience and holds the state responsible for safeguarding it"61.

Tunisia is the first country in the Middle East and North Africa (out of the states that had

57. See Houria Case, Cass, civ, Case law n³384, 31 January 1966 and Crim. $n^{\circ} 7795$.

58. Beji Caid Essebsi (29 November 1926 -25 July 2019) was the President of Tunisia from 31 December 2014 until his death on 25 July 2019. Previously, he served as Minister of Foreign Affairs from 1981 to 1986 and as Prime Minister from February 2011 to December 2011. In December 2014, he won the first regular presidential election following the Tunisian Revolution, becoming Tunisia's first democratically elected President in the post-Arab Spring era.

59. It was, in fact, merely the result of a 1973 decree issued by the Ministry of justice stipulating that any non-Muslim man seeking marriage to a Tunisian (presumptively Muslim) woman prove his Muslim status in the presence of one of the Republic's Muftis.

60. See https://aventina.it/908/news/tunisian-women-arenow-free-to-marry-non-muslims/

61. https://howafrica.com/top-10-powerful-politicalstatements-by-african-leaders-in-2017/ 
had this law to begin with) to remove this law ${ }^{62}$. Finally, after many campaigns put together by numerous human rights groups, the law has been abolished, and from now on, Tunisian women may marry whoever they want. Tunisian women have as equal rights as men, defying the conventional social standards ${ }^{63}$.

However, since the 1973 decree was repealed, the battle over mixed marriages is still on as the Tunisian civil society tries to adapt to the new law with tensions between conservative and progressive forces ${ }^{64}$.

\section{SECTION 4. EVOLUTION OF THE QUESTION RELATED TO SUCCESSION AND EQUALITY OF WOMEN AND MEN IN INHERITANCE}

At the initiative of former President of Tunisia Beji Caid Essebssi ${ }^{65}$, a draft law was submitted to Parliament amending the Personal Status Code, in order to establish inheritance equality between men and women in Tunisia. Such a law would represent a break with a Quranic directive, still in force today in Tunisia and which classical Islamic jurisprudence deems unambiguous and not subject to interpretation, whereby a woman's share is only half of what a man receives ${ }^{66}$.

62. See BEN ACHOUR, S. (2013), "Féminismes laics en pays d'Islam », in Mélanges Kalthoum MEZIOU-DOURAI, La diversité dans le droit, $C P U$, Tunis, pp. 53-67.

MARZOUKI, I. (2013), "La sécularisation, façon tunisienne », in Mélanges Kalthoum MEZIOU-DOURAI, La diversité dans le droit, CPU, Tunis, pp.639-646.

63. See BEN ACHOUR, S. (2005), « Figures de l'altérité. A propos de l'héritage du conjoint non musulman », in Mélanges Sassi BEN HALIMA, Mouvements du droit contemporain, CPU, Tunis, pp.823-840.

64. See CHEDLY, L. (2008), "Le mariage de la musulmane avec un non musulman entre texte et interprétation ", in Droits et Culture, Mélanges en l'honneur du doyen Yadh BEN ACHOUR, CPU 2008, pp.457 et ss.

NOUIRA A. (2008), " "Le mariage de la tunisienne musulmane avec un non musulman : Dépassement ou transgression des frontières?", GRIC, 2008

65. Beji Caied Essebsi was the President of Tunisia from 2014 to 2019.

66. See MEZGHANI, A. (2008), " Religion, Mariage et Succession : L'hypothèse laïque. A propos d'une évolution récente de la jurisprudence tunisienne », in Droits et Culture Mélanges en l'honneur du doyen Yadh BEN ACHOUR, CPU, pp.14 et ss; MEZGHANI, A. et MEZIOU, K. (2006), L'égalité entre Hommes et Femmes en matière successorale, Sud Editions, Tunis.
The former Tunisian President Beji Caid Essebssi said in his speech, during celebrations of the National Women's day, 13 August 2017, that the marriage law was "an obstacle to the freedom of choice of the spouse". He hoped that the country will reach "total, actual equality between men and women citizens in a progressive way." He saied also that: "The state is obliged to achieve full equality between women and men and to ensure equal opportunities for all responsibilities" 67 .

The former Tunisian President has proposed that the future law should allow for a will maker the option of rejecting inheritance equality and reverting to the earlier system. This was in response to a proposition from the Individual Freedoms and Equality Committee (IFEC) ${ }^{68}$ chaired by Bochra Hadj Hmida. The Committee has the task of singling out any legislative dispositions contrary to the principles of liberty and equality, as set forth in the 2014 Constitution, and suggesting possible amendments ${ }^{69}$.

For the members of the Individual Freedoms and Equality Committee, this idea is the translation of the article 21 of the Tunisian Constitution on the basis of a total equality between men and women.

67. The former Tunisian President Beji Caid Essebsi made this announcement on the occasion of the women's Day in Tunisia 13 August 2017. In a televised address marking, he described the inheritance equality measure as long overdue: "I propose that equality in matters pertaining to inheritance be signed into law by modifying the code of personal status," he said, referring to a series of laws initiated post-independence in the mid-1950s that revolutionized women's rights, most markedly through abolishing polygamy and legalizing abortion.

Observers also note ESSEBSI's ideological proximity to Tunisia's founding father, Habib Bourghiba, who spoke vociferously in favour of women's emancipation. See https://www.aljazeera. com/news/2018/08/tunisia-president-vows-give-womenequal-inheritance-rights-180813172138132.html

68. The Individual Freedoms and Equality Committee (COLIBE, in French Commission des libertés individuelles et de l'égalité) is a commission created by the former President of Tunisia Beji CAID ESSEBSI on 13 August 2017.

The Committee is charged with contributing to the state of individual freedoms and equality in Tunisia through the preparation of a reform project in accordance with the requirements of the Tunisian Constitution of 2014 and international human rights standards. Indeed, according to this Commission, the Tunisian Constitution includes a number of chapters on individual freedoms and the principles of equality while many legislation and laws inherited from the French protectorate and the dictatorship are incompatible with the principles and spirit of contained changes. See https://colibe. org/la-commission /?lang=en

69. See Individual Freedoms and Equality Committee Report (in Arabic), 1st June 2018, available at : https://www.legal-agenda. com/ uploads/Rapport-COLIBE.pdf 
The Article 21 provides that: " 1 . All citizens, male and female, have equal rights and duties, and are equal before the law without any discrimination. 2. The state guarantees freedoms and individual and collective rights to all citizens, and provides all citizens the conditions for a dignified life".

After the Tunisian Cabinet approved, in 23 November 2018, the Draft law that would allow men and women to inherit equal amounts, contrary to what is stipulated in Islam, it should be discussed and ratified in Parliament before it goes into effect.

If it is voted by the Parliament, Tunisia will become the first Arab country to achieve gender equality in inheritance. However, the death of Beji Caid Essebsi in July 2019 and the coming of Kais Saied to power, since October 2019, slowed the momentum of the project. As a matter of fact, the current Tunisian President Kais SAIED ${ }^{70}$ has taken conservative positions on women's issues as well, coming out against gender equality in inheritance issues, in accordance with the interpretation of religious $\operatorname{law}^{71}$. For instance, this position arranges Ennahdha, the majority party in the Tunisian Parliament.

\section{SECTION 5. RESPECT OF INTERNATIONAL LEGAL FRAMEWORK ON RELIGIOUS FREEDOM AND UN TREATY BODIES RECOMMENDATIONS TO TUNISIA}

The right of religious freedom is upheld foremost in International agreement ${ }^{72}$. According to article 18 of the Universal Declaration of Human Rights of 10 December 1948 "Everyone has the right to freedom of thought, conscience and religion; this right includes freedom to change his religion or belief, and freedom, either alone or in community with others and in public or private, to manifest his religion or belief in teaching, practice, worship and observance".

70. Kais Saied (22 February 1958) is a Tunisian politician, statesman, jurist and former lecturer serving as the President of Tunisia since October 2019.

71. https://www.nouvelobs.com/monde/20190917.OBS18538/ robocop-ultra-conservateur-10-choses-a-savoir-sur-kais-saied. html

72. WEHRENFENNIG, D. (2006), "The Human Right of Religious Freedom in International Law", in Peace Review, 18:3, 403-410.
The Universal Declaration's commitment to the fundamental right of freedom of religion or belief of 1981 was embodied in Article 18 of the International Covenant on Civil and Political Rights of 16 December 1966 which states that: " 1 . Everyone shall have the right to freedom of thought, conscience and religion. This right shall include freedom to have or to adopt a religion or belief of his choice, and freedom, either individually or in community with others and in public or private, to manifest his religion or belief in worship, observance, practice and teaching. 2 . No one shall be subject to coercion which would impair his freedom to have or to adopt a religion or belief of his choice. 3. Freedom to manifest one's religion or beliefs may be subject only to such limitations as are prescribed by law and are necessary to protect public safety, order, health, or morals or the fundamental rights and freedoms of others. 4. The States Parties to the present Covenant undertake to have respect for the liberty of parents and, when applicable, legal guardians to ensure the religious and moral education of their children in conformity with their own convictions". This Covenant is a legally binding treaty obligation for States Parties to $\mathrm{it}^{73}$.

Moreover, the Declaration on the Elimination of All Forms of Intolerance and of Discrimination Based on Religion or Belief of 1981, although not formally binding as a treaty obligation, distills many of the principles articulated in the ICCPR. Article 1 of the 1981 Declaration merely repeats, verbatim, the language of the first three paragraphs of Article 18 of the ICCPR ${ }^{74}$.

Also, article 14 of the United Nations Convention on the Rights of the children of 20 November 1989 provides that:" 1 . States Parties shall respect the right of the child to freedom of thought, conscience and religion. 2. States Parties shall respect the rights and duties of the parents and, when applicable, legal guardians, to provide direction to the child in the exercise of his or her right in a manner consistent with the evolving capacities of the child. 3. Freedom to manifest one's religion or beliefs may be subject only to

73. Tunisia signed this Covenant on 20 April 1968 and ratified it on 18 March 1969.

74. DURHAM, C. (1999), "Freedom of religion or belief: laws affecting the structuring of religious communities", Organization for Security and Co-operation in Europe, Review Conference, September 1999, ODIHR Background Paper 1999/4, https:// www.refworld.org/pdfid/3e283bd01.pdf 
such limitations as are prescribed by law and are necessary to protect public safety, order, health or morals, or the fundamental rights and freedoms of others".

Tunisia had ratified all these texts ${ }^{75}$. Its new Constitution of 2014 and other legal texts on the matter are in conformity with these international standards of freedom of religion. According to article 20 of the Tunisian Constitution, "International agreements approved and ratified by the Assembly of the Representatives of the People have a status superior to that of laws and inferior to that of the Constitution".

Since the state is the guarantor of freedom of conscience, it is entirely logical that it prohibits any discrimination based on religion. When reading the article 21 of the Tunisian Constitution, which provides that "the citizens are equal before the law without discrimination ", one should therefore not find in Tunisian legislative provisions, any reference establishing the difference in treatment between individuals regardless of gender, origin, race, or religion.

However, it is important to recall the Article 49 of the Tunisian Constitution which determines the restrictions that may be placed on the rights and freedoms and which must themselves meet three conditions. The first one being that these different restrictions can only take the form of a law. Secondly, it must not harm the essence of these different rights and must be necessary in a civil state for reasons of public security, national defense, public health or morals public. Thirdly, the obligation to protect rights and freedoms belongs to the judicial authorities. In this regard, we can consider that this is another aspect of the Constitution that presents a potential problem for religious freedom. The real concern comes from the language of "public order," and "public morals". This language is extremely vague and open to interpretation. Consequently, public morals, in particular, could be used to justify restrictions on religious freedom.

75. Ratification Status for Tunisia, UN Treaty Body Database, https://tbinternet.ohchr.org/_layouts/15/TreatyBodyExternal/ Treaty.aspx?CountryID $=178 \&$ Lang $=E N$
Ensuring that the rights guaranteed in the Tunisian Constitution are not infringed upon is the job of the courts. However, till now, Tunisia is unable to form its Constitutional Court. "This removes the judicial backstop meant to protect citizens from having their constitutional rights infringed upon"76. For instance, the Provisional Authority in charge of determining the constitutionality of laws created in 2014, is only competent to review draft laws. "Without the full constitutional court in place, there is no body in Tunisia that can properly rule on constitutional questions"77.

As a matter of fact, theoretically, it is possible to affirm that the Tunisian Constitution of 2014 is in adequacy with the International standards protecting the religious freedom, as well as it gives a precise definition of their exercise and restriction framework. In addition, the Tunisian constitution provides the necessary guarantees in order to best ensure the respect and exercise of rights and freedoms, in general, and particularly freedom of thought, conscience and religion.

However these normative standards can face a lot of challenges, once they are in practice ${ }^{78}$. In this regard, we can mention, interalia, the recommendations done to Tunisia by the UN treaty bodies, as for example the Concluding observations of the Committee on the Elimination of Discrimination against Women in 2010:" 10. The Committee recalls the obligation of the State party to systematically and continuously implement all the provisions of the Convention on the Elimination of All Forms of Discrimination against Women and views the concerns and recommendations identified in the present concluding observations as requiring the State party's priority attention between now and the submission of the next periodic report. Consequently, the Committee urges the State party to focus on those areas in its implementation

76. BITZ, A. (2019), "Freedom of Religion in the 2014 Tunisian Constitution", op. cit.

77. Idem. op. cit.

78. See ZAID, A. and BEN ROMDHANE, D. (2014), "Tunisia's new constitution: progress and challenges to come", Open Democracy, February 16, 2014.

ZEMNI, S. (2015), "The Extraordinary Politics of the Tunisian Revolution: The Process of Constitution Making", Mediterranean Politics, 20(1), 1-17. 
activities and to report on action taken and results achieved in its next periodic report"79.

Concerning the discriminatory laws, Tunisia was asked the following: " 17.The Committee calls upon the State party to give high priority to the completion of the necessary legislative reforms and to modify, or repeal, without delay and within a clear time frame, discriminatory legislation, including discriminatory provisions in the Nationality Code, the Penal Code and the Code of Personal Status"80.

Furthermore, and concerning Marriage and family relations, the recommendations were the following: "60. While commending the State party for recent legislative amendments, including to the taxation law and to the Code of Personal Status with regard to the age of marriage and the possibility for a Tunisian women to transmit her nationality to her child under certain circumstances, the Committee remains concerned about the persistence of discrimination with regard to personal status, in particular concerning marriage, child custody and guardianship, as well as inheritance. In this respect, the Committee expresses its concern at an administrative regulation dated 1973 forbidding marriage between a Muslim Tunisian woman and a nonMuslim man, thus creating an impediment not foreseen by the Code of Personal Status. While noting the efforts of the State party to reduce the value of the dowry to one dinar, the Committee is concerned that it remains a condition for the validity of the marriage. The Committee notes also with concern that despite considerable efforts made to ensure equality of spouses during marriage and on its dissolution, the husband remains the head of the household, and is therefore entitled to choose the couple's domicile and to transmit his name and his nationality to the child. Furthermore, the Committee is concerned that mothers do not share parental responsibility on an equal footing with men and that they do not enjoy full guardianship rights.

79. Concluding observations of the Committee on the Elimination of Discrimination against Women, Committee on the Elimination of Discrimination against Women, Consideration of reports submitted by States parties under article 18 of the Convention, Forty-seventh session, 422 October 2010, CEDAW/C/ TUN/CO/6, p.3, https://tbinternet.ohchrorg/_layouts/15/ treatybodyexternal $/$ Download.aspx?symbolno $=C E D A W / C /$ TUN $/ C O / 6 \&$ Lang $=E n$

80. Idem. op. cit., p. 4.
The Committee also notes that, notwithstanding the February 2009 landmark decision of the High Court of Appeal, and the "retour" (reversion) mechanism introduced in the law of succession, discrimination in inheritance still persists "81.

This report dates from 2010. Meanwhile, Tunisia had done a lot in order to introduce reforms in its legal framework system in accordance with due respect to International instruments ratified by Tunisia and in accordance with the respect of the religious freedom announced in the 2014 Constitution, as mentioned above. Most of these recommendations are outdated today as Tunisia withdrew all specific reservations to the Convention on the Elimination of All Forms of Discrimination against Women (CEDAW).

Besides, on the question of freedom of thought, conscience and religion, the Committee on the Rights of the Child recommended the following to Tunisia in 2010:" The Committee notes that article 5 of the Constitution provides for the inviolability of the freedom of conscience and freedom of religious worship unless it disturbs public order. Nevertheless the Committee remains concerned at regulations prohibiting the wearing of an Islamic headscarf (hijab) by women and girls in Government offices and in schools and universities"82.

It is obvious that Tunisia, during its democratic transition since 2011, had done a lot of efforts in order to review such problems. The Constitution of 2014 replaced the Constitution of 1959 that was mentioned in this report. Furthermore, there no any regulations prohibiting the wearing of an Islamic headscarf (Hijab) by Tunisian women and girls nowadays, like it was the case under the former Tunisian President Zine El Abidine Ben Ali's regime. Things changed a lot since 2011.

Concerning the concluding observations of the Committee on the Elimination of Racial

\footnotetext{
81. Idem. op. cit., p. 13.
}

82. Committee on the Rights of the Child, Fifty-fourth session 25 May - 11 June 2010, Consideration of reports submitted by States parties under Article 44 of the Convention, Concluding observations of the Committee on the Rights of the Child: Tunisia RC/C/TUN/CO/3, p.7.

https://tbinternet.ohchr.org/_layouts/15/treatybodyexternal/ Download. aspx? symbolno $=C R C / C / T U N / C O / 3 \&$ Lang $=E n$ 
Discrimination made to Tunisia in $2010^{83}$, a lot of positive aspects were highlighted, especially the ones related to the principals of tolerance. In this regard, "6.The Committee welcomes the various measures taken to promote the principle of tolerance and the culture of human rights at all levels of education. It notes with interest the introduction of human rights education in the Higher Institute of the Judiciary, the Prison Officers College and the Police College. 7. The Committe welcomes the State party's continuing efforts to promote understanding, tolerance and friendship between peoples, civilizations and religions. It is particularly interested in the academic training provided at the University of Ezzitouna, which emphasizes the history of religions, human rights in sacred writings and interreligious dialogue" 84 . However, ten years after this report was made, things evolved in Tunisia. Because of the freedom of expression and the multiple tensions between religious supporters and secular supporters, the principle of tolerance is completely challenged.

More recently, the UN Special Rapporteur on Freedom of Religion or Belief mentioned in his report of 2018 on the Preliminary findings of his visit to Tunisia, the following observations: "The country continues to face numerous challenges to democratic consolidation. This includes economic challenges and difficulties with establishing key institutions mandated by the Constitution, such as the Constitutional Court; struggles with advancing initiatives that facilitate reviews and repeals laws that violate Constitutional standards and international human rights obligations; and uncertainty about the future of the country's transitional justice process. One of the key challenges facing the Government has been that of countering violent extremism and terrorism, which has both national and international dimensions. The national dimension involves several terrorist incidents, which have, in addition to random violence, also targeted politicians, civil society activists and tourists (...)"85.

83. Committee on the elimination of racial discrimination, Seventy-fourth session 16 February-6 March 2009, Consideration of reports submitted by states parties under article 9 of the convention, Concluding observations of the Committee on the Elimination of Racial Discrimination, Tunisia, CERD/C/TUN/ CO/19, 23 March 2009,

https://tbinternet.ohchr.org/_layouts/15/treatybodyexternal/ Download.aspx?symbolno $=C E \bar{R} D / C / T U N / C O / 19 \&$ Lang $=E n$

84. Idem. op. cit.

85. Preliminary findings of the visit to Tunisia by the UN Special
On another hand, the report mentioned more recent developments that illustrate Tunisia's strong commitment to equality and freedom of religion or belief. "These include the withdrawal of all substantive reservations to the UN CEDAW in April 2014, in addition to announcements of the Government's decision to rescind a circular dated 5 November 1973 that imposed a ban on marriages between Tunisian Muslim women and non-Muslim men in September 2017"86.

Having said that, extra challenges can be mentioned to show how difficult is the respect of the religious freedom and freedom of conscience in practice. For example, some provisions in the Tunisian Criminal Code $^{87}$ are still to be excluded to align Tunisian legal system with global human rights. These provisions, such as the article 230, are above human rights that protect the right to choose freely one's gender and sexual orientations, since they prohibit homosexuality and put individual with homosexual orientations up to penalties and imprisonment. Since Tunisia is a country where the main religion is Islam, that doesn't allow homosexuality, the fight is not easy to removing the penalties of homosexuality and it still persists. Another provision of the Tunisian criminal code prohibits sexual relations between consenting adults outside the matrimonial scope if were discovered by the law enforcers, and might even be qualified as secret prostitution. A commission of legal experts and eminent Professors is working on the reform of the Tunisian Criminal Code to align it to International standards of Human rights and liberties. Also, the process of transitional justice in Tunisia ${ }^{88}$ is still painful ${ }^{89}$.

Rapporteur on Freedom of Religion or Belief, 19 April 2018, https://www.ohchr.org/en/NewsEvents/Pages/DisplayNews. aspx?NewsID $=22956 \&$ LangID $=E$

86. Idem. op. cit.

87. The Tunisian Criminal Code was promulgated on 9 July 1913 , http://www.legislation.tn/en/affich-code/Codep\%C3\%A9nal_89

88. FERCHICHI, W. (2015), "La justice transitionnelle en Tunisie entre 2011 et 2014", in Mélanges Rafâa BEN ACHOUR, Les mouvances du droit, tome 1, pp. 283-306.

89. See TRABELSI, M. (2017), " Transitional Justice in Tunisia A Painful but Necessary Step Forward", IPI Global observatory, https://theglobalobservatory.org/2017/05/tunisia-truthdignity-commission-arab-spring/

ALMAJDOUB, S. (2017), "Transitional Justice in Tunisia: Challenges and Opportunities", Maydan Politics and society, https://themaydan.com/2017/05/transitional-justice-tunisiachallenges-opportunities/

GONZALEZ, R. (2019), "The tortuous path of transitional justice in Tunisia", Equal times, https://www.equaltimes.org/the- 
Moreover, the creation of a Zakat fund, that was inaugurated by El Kram Mayor Fathi Laayouni in Tunisia on 19 May 2020, has sparked fierce backlash from defenders of the country's civil state, who argue that religious initiatives should not replace the government's civic duty ${ }^{90}$. In Islam, Zakat is a religious prescription to donate a portion of one's income to the poor. In a response to Laayouni's move, Tunisia's Ministry of Local Affairs published a post on its Facebook account specifying that Zakat is not the same as a donation, suggesting that the creation of such a fund is not legal. Besides, the Tunisian Parliament had opposed a similar proposal in December 2019. The National Observatory for the Defence of the Civil Nature of the State said "the move reflected "disrespect for the State's institutions," and was "an act of defiance against the constitution," which affirms the civil nature of the Tunisian government"91. The Tunisian Human Rights League also denounced the establishment of the Zakat fund, arguing that this initiative "reflects a blatant disrespect of state institutions, especially since this project had been rejected by the House of People's Representatives"92 and reiterated that Tunisia is a civil state.

These are some examples of how complicated the interpretation of the provisions of the Tunisian Constitution will be, when it is question of human rights and public liberties. It shows the interest of speeding up the process of establishing the Constitutional Court in Tunisia ${ }^{93}$, which will be one of the guarantors of respect for religious freedom and freedom of belief, in case of doubt.

\section{CONCLUSION}

In this paper, it has been shown that the achievements of religious freedoms in Tunisia are mixed.

tortuous-path-of-transitional?lang=fr\#.XuQi99VKjIU

90. ZAYAT, I. (2020), "'Zakat fund' sparks heated controversy in Tunisia over role of religion in politics", in The ArabWeekly, https://thearabweekly.com/zakat-fund-sparks-heatedcontroversy-tunisia-over-role-religion-politics

91. Idem. op. cit.

92. Ibidem. op. cit.

93. See MEKKI, N. (2016), "The Tunisian Constitutional Court at the Center of the Political System - and Whirlwind", in Constitionet IDEA, http://constitutionnet.org/news/tunisianconstitutional-court-center-political-system-and-whirlwind
On one hand, the introduction of the freedom of conscience (Article 6 of the Tunisian Constitution) was considered as a constitutional revolution in Tunisia in 2014 , besides the reforms related to the questions of the marriage of a Muslim woman to a non-Muslim man and the one related to succession and equality in inheritance.

On the other hand, a lot of challenges remain especially in practice. The new democratic institutions in Tunisia are challenged to provide respect for human rights and fundamental freedoms, and to be able to guarantee the independence of justice.

In the area of religious freedom, the new Tunisian democracy is still feeling its way and "the fight for freedom of conscience, fundamental freedoms and human rights must continue in a steadfast, lucid and vigilant manner. It must be based on a dissemination of the democratic culture that constitutes its indispensable core"94.

The creation of new communication forums enables the civil society to transgress taboos and force politicians to resolve more urgent and current problems. But this doesn't relieve them of their responsibility for organizing suitable deliberations, identifying priorities and taking decisions capable to counteract the influence of ideologists.

Modernization must cease to be a goal promoted by the elite. It should be discussed and accepted by the people. It has to become the expression of the needs and desires of the populations in accordance to the principles of Democracy and rules of Law.

As a matter of fact, it will be up to the Tunisian Constitutional Court whose decisions are binding to all public authorities (under article 121 of the Tunisian Constitution) to lift the ambiguities and uncertainties left by the grantor, in particular regarding the questions of the exercise of worship, religious pluralism and equality, and end conflicts that may be generated by the implementation of articles first and two of the constitution. Certainly, the provisions of the constitution must be understood and interpreted in relation to others as a cohesive entity. Therefore, no article

94. FERJANI, M-C. (2018), "Tunisia: between Freedom of Conscience and Protection of the Sacred", op. cit. 
in the Constitution will prevail over another. The combination of articles 1, 2, 21 and 49 in particular should logically lead to dismiss any rule (whatever its source of inspiration) not respecting democratic values and who does not take the individual in his universal dimension.

However, currently, as the Constitutional court is not yet established, there is no constitutional control of newly adopted laws, apart the one from the Provisional Authority in charge of determining the constitutionality of laws. Human rights confirmed in the new Constitution are not correctly respected. This means that the role of the Constitutional Court will be crucial in order to enhance the application of the Laws in the field of Human rights and Liberties in Tunisia. This Court will be the guardian of Democracy, of the state of Law and of the best application of the International standards of International Human law. For the moment, the Interim Commission for the Review of the Constitutionality of Laws is the one responsible for that, till the creation of the Constitutional Court.

Besides, as part of the African Union, Tunisians can have the option of presenting their cases in front of the African Court of Human and People's Rights $^{95}$. Tunisia protects human rights by offering

95. The African Court on Human and Peoples' Rights is a regional jurisdiction that has been created to complement and support the African Commission on Human and Peoples' Rights, regarding the protection of human rights in Africa. The Protoco to the African Charter on Human and Peoples' Rights establishing and African Court on Human and Peoples' Rights" was adopted in 1998 and became operational on 25 January 2004, See BEKKER, G. (2007), "The African Court of Human and Peoples" Rights : Safeguarding the interests of African States", Journal of African Law, vol. 51. BEN ACHOUR, R. (2019), "L'islam dans the chance to any individual to access the African Court $^{96}$, as the declaration under Article 34(6) of the Protocol to the African Charter on Human and Peoples' Rights on the Establishment of an African Court on Human and Peoples' Rights, was signed in 2018.

Tunisia had accomplished a lot in very few years, in comparison with the other Arabic states of the MENA region. However the path to reach the goals of its revolution is still long and painfu ${ }^{97}$ . Tunisian Civil society, Tunisian women and Tunisian youth are still fighting to make all their dreams come true. This is not impossible. It is just a question of time.

le contentieux international des droits de l'homme : l'exemple de la Cour africaine des droits de l'homme et des peuples », in AFROUKH M. (2019) (dir.), L'islam et le droit international des droits de l'Homme, Paris, Institut Universitaire Varenne, Collection : Transition \& Justice

96. The non-governmental organisations and the individuals entitled with the observer status before the Commission can institute cases directly before the Court, if the State concerned has made a declaration accepting the competence of the Court to receive those cases, under penalty of non-admissibility (article 34(6) of the Protocol). Tunisia signed on April 18, 2017, the declaration under Article 34(6) of the Protocol to the African Charter on Human and Peoples' Rights on the Establishment of an African Court on Human and Peoples' Rights, which entitles NGOs with observer status before the African Commission on Human and Peoples' Rights and individuals to initiate cases directly before the Court against the State that signed the declaration, see GUELDICH, H. (2017), "Portée politique de la signature par la Tunisie de la déclaration d'acceptation de la juridiction de la Cour africaine des droits de l'Homme et des peuples pour recevoir les requêtes individuelles et celles des ONG", Leaders 20 April 2017, https://www.leaders.com.tn/article/22130

97. FERJANI, M-C. (2018), "Tunisia: between Freedom of Conscience and Protection of the Sacred", Religion and society, April 2018, https://www.oasiscenter.eu/en/tunisia-freedom-ofconscience-protection-of-sacred

\section{BIGLIOGRAFÍA}

\section{In English Language:}

- AL-ANANI, K. (2012). "Islamist Parties PostArab Spring", in Mediterranean Politics, $17(3)$.

- ANDERSON, L. (2011). "Demystifying the Arab Spring: Parsing the Differences between Tunisia, Egypt, and Libya", in Foreign Affairs, 90(2), 2-7.

- BITZ, A. (2019). "Freedom of Religion in the
2014 Tunisian Constitution", International Immersion program Papers, 100, https://chicagounbound.uchicago.edu/ international_immersion_program_ papers $/ 100$

- FERJANI, M-C. (2018). "Tunisia: between Freedom of Conscience and Protection of the Sacred", Religion and society, April 2018, https://www.oasiscenter.eu/en/ 
tunisia-freedom-of-conscience-protection-ofsacred

- IHSAN, M. and ZEBA Kk. (2011). "Secularreligious tensions in Tunisia since 2011", in KUMARASWAMY, Pr. and al, Islamic movements in the Middle east: ideologies, practices and political participation, KW Publishers, New Delhi, pp. 143-167.

- JOFFE, G. (2011). "The Arab Spring in North Africa: origins and prospects". North African Studies, 16(4), 507-532.

- KHEDHER, R. (2017), "Tracing the Development of the Tunisian 1956 Code of Personal Status", in Journal of International Women's Studies, 18(4), 30-37. Available at: http://vc.bridgew.edu/jiws/vol18/iss4/3

- MABROUK, M. (2011). "A revolution for dignity and freedom: preliminary observations on the social and cultural background to the Tunisian revolution", in The Journal of North African Studies, 16(4), 625-635.

- MEKKI, N. (2020), « The democratic transition in Tunisia: Three explicative keys to understand a success story ", in EL ISSAWI F and CAVATORTA F. (ed), The Unfinished Arab Spring, Micro Dynamics of Revolts Between Change and Continuity, University of Chicago Press/Ginko Press.

- PERKINS, K. (2014). A History of Modern Tunisia (2nd ed.), Cambridge: Cambridge University Press.

- PICKARD, D. (2012), "The Current Status of Constitution Making in Tunisia, Carnegie Endowment For International Peace" (Apr. 19, 2012), http://carnegieendowment. org / 2012 / 04 / 19/current-statusof-constitution-making-in-tunisia/ ah1s.

- GOODENOUGH, P. (2012), "Sharia Rises in Tunisia's Constitution-Drafting Process", cnsnews.com (Mar. 2, 2012).

- MANAA, M. (2012), "Tunisia's Constitution: The Battle for Islam and Democracy", Fair Observer (Dec. 7, 2012), http:// www.fairobserver.com/article/ tunisias-constitution-battle-islam-democracy.

- LAMBOLEY C. (2012), "Tunisia's Leading Party Reaffirms Commitment to Arab-Muslim Identity", Tunisialive (Mar. 25, 2012), http:// www.tunisia-live.net/2012/03/26/tunisiasleading-party-reaffirms-commitment-toarab-muslim-identity/

- SCHÄFER, I. (2015), The Tunisian Transition: Torn Between Democratic Consolidation and Neo-Conservatism in an insecure region context, IeMed and EuroMesco, 2015.

- ZAID, A. and BEN ROMDHANE, D. (2014), “Tunisia's new constitution: progress and challenges to come." Open Democracy, February 16, 2014.

- ZEMNI, S. (2015), "The Extraordinary Politics of the Tunisian Revolution: The Process of Constitution Making", Mediterranean Politics, 20(1), 1-17.

\section{In French Language:}

- AMOR, A. (2010), "Interrogations sur la liberté de religion ou de conviction », in Droit, pouvoir et religion, A.T.D.C., pp. 217 et ss.

- BAKIR, M. (2016), Laïcité et religion en Tunisie, Thèse de doctorat, Linguistique, Soutenue le 16 septembre 2016, Université de Strasbourg.

- BEN ACHOUR, R. (2019), " L'islam dans le contentieux international des droits de l'homme : l'exemple de la Cour africaine des droits de l'homme et des peuples", in AFROUKH M. (dir.), L'islam et le droit international des droits de l'Homme, Paris, Institut Universitaire Varenne, Collection : Transition \& Justice.

- BEN ACHOUR, R. et GUELDICH, H. (dir.) (2017), Dictionnaire de la nouvelle Constitution Tunisienne, Tunis, Simpact.

- BEN ACHOUR, S. (2013), « Féminismes laics en pays d'Islam », in Mélanges Kalthoum MEZIOU-DOURAI, La diversité dans le droit, CPU, Tunis, pp. 53-67.

- BEN ACHOUR, S. (2005), « Figures de l'altérité. A propos de l'héritage du conjoint 
non musulman », in Mélanges Sassi BEN HALIMA, Mouvements du droit contemporain, CPU, Tunis, pp.823-840.

- BEN ACHOUR, Y. (2016), Tunisie: une révolution en pays d'islam, Cérès éditions, Tunis.

- BEN ACHOUR, Y. (2011), La deuxième Fâtiha: l'islam et la pensée des droits del 'Homme, Cérès éditions, Tunis.

- BEN ACHOUR, Y. (2008), Aux fondements de l'orthodoxie sunnite, Cérès éditions, Tunis.

- BEN ACHOUR, Y. (2008), "Droits du croyant et droits de l'homme, Un point de vue islamique", islamo -christiana, Roma, $\mathrm{N}^{\circ} 39$.

- BEN ACHOUR, Y. (1993), Normes, foi et loi, Cérès éditions, Tunis.

- BEN HALIMA, S. (2000), « Religion et Statut Personnel en Tunisie », in Revue Tunisienne de Droit, pp. 107 et ss.

- BEN JEMIA, M. (2007), "Constitutionnalisation du droit et mutation du statut personnel", in Cours de l'académie internationale de droit constitutionnel, 23ème session, Tunis 2007, pp. 1 et ss.

- BOUGUERRA, M. (2005), « Le Code tunisien du statut personnel, un code laïque ? » in Mélanges Sassi BEN HALIMA, Mouvements du droit contemporain, CPU, Tunis, pp. 529-581.

- CHARFI, A. (2008), « Islam alibi, islam assumé », in Mélanges Yadh BEN ACHOUR, Droits et culture, CPU, Tunis, 2008, pp. 71-81.

- CHARFI, A. (2004), L'Islam entre le message et l'histoire, Tunis, Sud Éditions.

- CHEDly, L. (2008), « Le mariage de la musulmane avec un non musulman entre texte et interprétation ", in Droits et Culture, Mélanges en l'honneur du doyen Yadh BEN ACHOUR, CPU 2008, pp.457 et ss.

- DABBABI, Kh. (2015), "La liberté religieuse dans la Constitution tunisienne du 27 janvier 2014", in BEN ACHOUR R., (dir.), Les nouvelles Constitutions arabes: Tunisie, Egypte (ouvrage collectif), Actes de colloque organisé par l'Unité de recherche en droit international, juridictions internationales et droit constitutionnel comparé, Tunis , 29 février et 1 mars 2014, Tunis, Simpact, pp. 71-77.

- DJAIT, H. (2013), La crise de la culture islamique, Cérès éditions, Tunis.

- FERCHICHI, W. (2015), "La justice transitionnelle en Tunisie entre 2011 et 2014", in Mélanges Rafaâ BEN ACHOUR, Les mouvances du droit, tome 1, pp. 283-306.

- FERCHICHI, W. (dir.), (2015), Libertés religieuses en Tunisie, Conférence de l'ADLI, Tunis, 13 février 2015.

- GOUIA, S. (2015), "La religion dans la nouvelle constitution tunisienne du 27 Janvier 2014 : Contexte et problématique", in Mélanges Rafaâ BEN ACHOUR, Les mouvances du droit, tome 1, pp. 359- 376.

- HAMMAMI, N. (2018), "La société tunisienne à l'égard de la liberté religieuse et de la conviction selon « le rapport sur l'état religieux en Tunisie (2011-2015) », in Liberté de religion et de conviction en Méditerranée :les nouveaux défis, Beït Al-Hikma - Carthage, conférence internationale des 27 et 29 septembre 2018.

- HAMDAM, N. (2013), La liberté de religion dans les Etats de droit musulman. Droit. Université Jean Monnet - Saint-Etienne.

- KLIBI, S. (2008), « Etat de droit, Etat laïque : Liberté religieuse ou déni de la religion? », in Mélanges Yadh BEN ACHOUR, Droits et culture, CPU, Tunis, pp. 153-169.

- LAGHMANI, S. (2000), "Entre Etat laïc et Etat confessionnel : Un statut intermédiaire estil pensable?", in Mélanges en l'honneur de Habib Ayadi. Tunis, CPU, pp.625-633.

- LHERNOULD,N.(2014),"Nouvelleconstitution tunisienne et liberté de conscience", in L'œuvre d'orient, https://oeuvre-orient.fr/ actualites/nouvelle-constitution-tunisienneliberte-de-conscience/

- LIMAM, J., (2015), "La liberté de religion: les dimensions de l'ambivalence", in FERCHICHI, W. (dir.), Libertés religieuses en Tunisie, Conférence de l'ADLI, Tunis, 13 février 2015, FSJPST, pp. 34-58.

- MARZOUKI, I. (2013), « La sécularisation, 
façon tunisienne ", in Mélanges Kalthoum MEZIOU-DOURAI, La diversité dans le droit, CPU, Tunis, pp.639-646.

- MEZGHANI, A. (2008), "Religion, Mariage et Succession : L'hypothèse laïque. A propos d'une évolution récente de la jurisprudence tunisienne », in Droits et Culture, Mélanges en l'honneur du doyen Yadh BEN ACHOUR, CPU, pp.14 et ss.

- MEZGHANI, A. et MEZIOU, K. (2006), L'égalité entre Hommes et Femmes en matière successorale, Sud Editions Tunis.

- MEZIOU, K. (2017), " Le Code du statut personnel : le texte et le contexte", in M'RAD, H. (sous dir.), Transitions arabes: Révoltes, Gouvernance et Géopolitiques, Tunis, éditions Nirvana, pp. 161-172.

- NOUIRA, A. (2008), «Le mariage de la tunisienne musulmane avec un non musulman
: Dépassement ou transgression des frontières ?», GRIC.

- REDISSI, H. (2011), La tragédie de l'Islam moderne, Cérès éditions, Tunis

- REDISSI, H. (2005), L'exception islamique, Cérès éditions, Tunis.

- SAYADI, A. (2018), "Peut-on séparer le religieux etlepolitique dansun pays musulman ? Que nous dit l'expérience tunisienne ?", in Liberté de religion et de conviction en Méditerranée :les nouveaux défis, Beït Al-Hikma-Carthage, conférenceinternationale des 27 et 29 septembre 2018.

- TALBI, M. (2011), Ma religion c'est la liberté: l'Islam et les défis de la contemporanéité, Nirvana éditions, Tunis.

- TALBI, M. (1998), Plaidoyer pour un Islam moderne, Cérès éditions, Tunis. 